\title{
PROVENANCE STUDY OF EARLY BRONZE AGE ARTEFACTS \\ FOUND IN ASTURIAS (SPAIN) BY MEANS OF METAL \\ IMPURITIES AND LEAD, COPPER AND ANTIMONY ISOTOPIC COMPOSITIONS
}

\begin{abstract}
A. REGUERA-GALAN ${ }^{1}$, T. BARREIRO-GRILLE ${ }^{1}$, M. MOLDOVAN ${ }^{1}$, L. LOBO ${ }^{1}, \mathrm{M}$. ÁNGEL DE BLAS CORTINA ${ }^{2}$, J. IGNACIO GARCÍA ALONSO ${ }^{1 *}$
\end{abstract}

1. Department of Physical and Analytical Chemistry, University of Oviedo. Julían Clavería, 8, 33006 - Oviedo (Spain)

2. Department of History, University of Oviedo. Teniente Alfonso Martínez s/n, 33011 - Oviedo (Spain)

${ }^{*}$ Author to whom correspondence should be addressed:

phone number: +34 985103484

e-mail address: jiga@uniovi.es 


\section{ABSTRACT}

We describe here the first combined isotopic and impurities study on 27 copper artefacts found in the northwest of Spain. This study follows previous studies on the lead isotopic composition of copper ores in three local mines that were exploited during the Bronze Age. The levels of impurities found were clearly different from ingots and axes with ingots having a much higher levels of impurities. It was not possible to differentiate the origin of the artefacts only by the impurities present. On the other hand, the lead isotopic composition indicated that all artefacts were prepared from local ores being the "La Profunda" mine the most probable source for most artefacts which carried out a clear radiogenic lead signature. The copper isotopic composition seemed to be able to differentiate between artefacts from "El Aramo" mine from those from "El Milagro" and "La Profunda" mines. On the other hand, the antimony isotopic signature was not useful for source allocation.

KEYWORDS (10 MAX): Early Bronze Age metallurgy, isotopic analyses, trace element analysis, provenance studies, North-west Iberia 


\section{INTRODUCTION}

The possibility of establishing a direct correspondence between a metallic artefact and its ore source has always been one of the most appealing goals in the archaeological field. As metal objects have played an essential role in most post-Neolithic societies, metal provenance studies help the archaeologists in the investigation of ancient mining activities, manufacturing technologies and in the reconstruction of trading routes, allowing a better understanding of the social, economic and political practices of ancient civilizations (Rehren and Pernicka 2008). Nowadays, scientific methods are applied to address these archaeological questions, and isotopic analysis has gained importance as a powerful tool for provenance studies (Desaulty et al. 2011). The isotopic composition of certain elements in the manufactured object provides a fingerprint that, once accurately measured, allows its comparison to isotopic data from different possible ore sources. In most cases, it is not possible to demonstrate a clear origin of the artefacts (Budd et al, 2000) but the measurements allow discarding ore sources whose isotopic data is far from that measured in the artefact. In this sense, the evaluation of lead isotopic composition is a well-established method for provenance studies in archaeometry but requires combination with other measurements.

Lead, commonly found in minerals and archaeological metal artefacts as a trace or minor constituent, consists of four stable isotopes: ${ }^{204} \mathrm{~Pb},{ }^{206} \mathrm{~Pb},{ }^{207} \mathrm{~Pb}$ and ${ }^{208} \mathrm{~Pb}$. While ${ }^{204} \mathrm{~Pb}$ concentration remained constant in nature since the formation of the Earth, the amount of ${ }^{208} \mathrm{~Pb},{ }^{207} \mathrm{~Pb}$ and ${ }^{206} \mathrm{~Pb}$ has changed over the years due to the radioactive decay of ${ }^{232} \mathrm{Th},{ }^{235} \mathrm{U}$ and ${ }^{238} \mathrm{U}$, respectively, resulting in a large natural isotopic variability (Catanzaro et al. 1968). Therefore, depending on the relative proportions of U-Th- $\mathrm{Pb}$ and the radioactive decay rate of $U$ and Th, different geological formation processes will show variable lead isotopic compositions (Baron et al. 2014). Due to the high mass of lead and the small relative mass difference between ${ }^{204} \mathrm{~Pb}$ and ${ }^{208} \mathrm{~Pb}(\sim 2 \%)$, no natural isotopic fractionation is observed, and the $\mathrm{Pb}$ isotopic fingerprint of the ore is 
transferred unalterably to the final object during smelting and manufacturing (Villa 2009), enabling the use of the lead isotopic composition as origin indicator. First used by Brill and Wampler (1965) and Gögler et al. (1966) 50 years ago, lead isotopic analysis has been widely employed for the determination of the geological origin of the metals used in artefacts such as jewellery (Yener et al. 1991), axes (Webb et al. 2006), water pipes (Durali-Mueller et al. 2007), coins ( Stos-Gale and Gale 2009), crossbow bolt heads (Thibodeau et al. 2012) and vessels (Mu et al. 2014), among others. However, the possibility of mixing and recycling of copper artefacts from different origins may obscure the lead isotopic signature of the ore sources and this fact has to be taken into account in the interpretation of the data, particularly for late Bronze Age objects.

With the introduction and development of multicollector ICP-MS instrumentation in the last few decades, the interest of isotopic composition analyses for provenance studies has markedly increased (Balcaen et al. 2010), and now, this technique is not only applied to the study of natural variations of radiogenic elements $(\mathrm{Pb}, \mathrm{Sr}, \mathrm{Nd}, \ldots)$, but also to elements prone to mass-dependent fractionation such as Zn (Cloquet et al. 2008), Sn (Haustein et al. 2010), Ag (Desaulty et al. 2011) or Cu (Balliana et al. 2013). Among them, copper is frequently used as a complementary provenance indicator to lead isotopic composition (Klein et al. 2004, 2010; Desaulty et al. 2011). Its potential arises from (i) the isotopic fractionation that its two isotopes $\left({ }^{63} \mathrm{Cu}\right.$ and $\left.{ }^{65} \mathrm{Cu}\right)$ undergo during geochemical processes (Klein et al. 2010), resulting in a small range of natural variation $(\delta \mathrm{Cu})$, and (ii) as pointed out by Gale and colleagues (1999), fractionation of the isotopic composition of copper does not occur during smelting and fire refining processes thought to have been used in ancient times. Although in the epsilon range $(\varepsilon)$, antimony isotopic natural variation has been recently proposed as geochemical tracer too: ${ }^{121} \mathrm{Sb}$ and ${ }^{123} \mathrm{Sb}$, with only a mass difference of $1.6 \%$, are subjected to isotopic fractionation due to physicochemical processes (Rouxel et al. 2003). Only a 
few publications have discussed its use as proxy for provenance studies of stibnites and ancient glass (Lobo et al. 2012, 2013, 2014) and for tracking pollution sources in mining regions (Resongles et al. 2015). Both studies achieved satisfactory results, predicting a promising future for the use of $\mathrm{Sb}$ isotopic composition as a reliable provenance tool.

Metal archaeological artefacts in the Copper and Bronze Ages were generally made of copper or copper alloys such as bronze or brass, that were accompanied by elemental impurities (As, $\mathrm{Ag}, \mathrm{Sb}, \mathrm{Bi}, \mathrm{Co}, \mathrm{Ni}, \mathrm{Zn} . .$. ) transferred from the ore source. A typical composition in the Copper Age and early Bronze Age in the Iberian peninsula was arsenical copper with arsenic levels between 0.1 and $6 \%$ (Sangsmeister 1960). The provenance discriminating potential of the metal trace content of an artefact is still under debate: the question about the behaviour of these elements during extraction, smelting and casting, and if their concentration remains invariable or not along these processes has been thoroughly discussed (Pernicka 1999; Pollard et al. 2007; Albarède et al. 2012). In this sense, regarding the conclusions obtained by Pernicka (1999), and further discussed by Ling and co-workers (2013), the concentration of elements such as gold, silver or nickel, can be considered quite stable, whereas arsenic or antimony may be partly lost during different processes due to their volatility and oxidation capabilities. Nevertheless, metal trace content is still useful, and a great number of works rely on its use as a complementary tool to lead isotopic analysis (Niederschlag et al. 2003; Kuleff et al. 2006; Cattin et al. 2011; Ling et al. 2014).

In this way, the main objective of the present work is to make use of the information yielded by metal trace content, lead, copper and antimony isotopic compositions to determine the origin of 27 Bronze Age artefacts found in four archaeological hoards in Asturias (northern Spain), and if possible, to postulate hypothetical metal trading routes exploited in ancient times. The lead isotope composition will be compared with the data from copper ores in different ancient copper mines in the same region (Huelga-Suarez 
et al. 2012, 2014a, 2014b) and with additional data published for lead isotopes in the Iberian Peninsula.

HISTORICAL COPPER WORKINGS IN NORTHERN SPAIN DURING THE BRONZE AGE: ARCHAEOLOGICAL CONTEXT IN ASTURIAS AND LEÓN

Mining has been a productive activity directly linked to the cultural, economic and social history of civilizations. In Eurasia,many influential cultures flourished in metal-rich areas. The use of determined minerals was not randomly performed but based on its particular properties, resulting in the growth, evolution and transformation of ancient communities (Rehren and Pernicka 2008). In this context, its high electrical conductivity, its excellent recycling properties and its ease to form alloys, made copper one the most appreciated metals. Regarding copper mining, Spain was considered one of the main metal-producing areas in Western Europe during Bronze Age and Roman period, with a great number of ores distributed along its territory (Carbonell TrilloFigueroa 1954; Fuste 1982; Armada 2005). In the north-western region of Spain, El Aramo, El Milagro and La Profunda mines (see Figure 1) constitute the most important testimony of ancient copper working to whom a large-scale prehistoric exploitation can be ascribed. These three mines are situated in the Cantabrian Mountains region, with a predominant limestone-based geological bead. Radiocarbon analyses of faunal tools and mammals/human remains found in their galleries dated the beginning of the three exploitations back to around the first half of the third millennium (ca. $2500 \mathrm{BC}$ ), partly coinciding with the Bell-Beaker metallurgical societies, demonstrated that mining activity continued for up to a thousand years (final radiocarbon dates were ca. 1500 BC) covering a period of time from the Copper Age to the Early Bronze Age (De Blas Cortina 1996, 2005, 2007, 2014; De Blas Cortina and Suárez Fernández 2009, 2010). 
Detailed data on these three mines including lead isotope ratios has been published recently (Huelga-Suarez et al. 2012, 2014a, 2014b).

Particularly, the mining complex of El Aramo, located in the heart of the Sierra El Aramo (center of Asturias) between altitudes of 1116 and $1223 \mathrm{~m}$, represents one of the biggest subterranean prehistoric mining complexes in Western Europe, composed of an extensive system of galleries, pits and wide excavations (De Blas Cortina 2014). The large-scale extraction activity from this mine, with a total mass of ca. 6708 Tons extracted, can only be explained by a strong intra and interregional demand of material. It has been indicated that a shafthole axe from Bohuslän (Sweden) dated 1600-1500 cal. BC may have originated from this mine (Ling et al 2014). Actually, human remains found in already exploited galleries in El Aramo mine could be interpreted as offerings to gods of the underworld as a compensation for such an extraction of subterranean wealth (De Blas Cortina 2010).

No more than 70 kilometers away is situated the El Milagro mine. Located in a copper carbonate-containing limestone hillside between altitudes of 300 and $380 \mathrm{~m}$ in the Güeña River basin (eastern Asturias) (Huelga-Suarez et al. 2014a), El Milagro excavations consisted in a narrow net of pits wherein ashes, burnt wood and charred rocks remains confirmed the use of fire-setting techniques to extract the mineral. Also, as observed in the El Aramo mines, human remains were found within the galleries, presumably attributed to ritual practices too.

In the neighbouring region of León is the La Profunda mine. Located in the southern hillside of the Sierra de Los Currilliles at an altitude of $1486 \mathrm{~m}$ (Huelga-Suarez et al. 2014b), La Profunda complex is considered the most important ancient copper mine of the whole northern region of the peninsular Meseta due to its considerable production: more than $18000 \mathrm{~m}^{3}$ of rock and mineral with an $5 \%$ average copper content were extracted during prehistoric excavations (Soler 1883). Rich in copper, cobalt, nickel and 
arsenic (Paniagua et al. 1987), the presence of uranium minerals results in a wide range of radiogenic lead isotopic variability, making this mine unique in terms of lead isotopic composition. Due to its significant mineral wealth, all these three important prehistoric mining complexes were again exploited in the last two centuries.

This large production of copper in ancient times is also confirmed by the vast number or archaeological copper artefacts found in this region (De Blas Cortina 2011). The 27 archaeological pieces under examination come from the "Asiego", "Gamonedo", "Cueva del Cuélebre" (Cuelebre cave) and "Gueraño" hoards which are described in the Experimental part. All these hoards were located in the eastern part of the Asturian province (see Figure 1), in the near vicinity of El Milagro mine. This region is characterized by a copper carbonate-rich (mainly malachite and azurite) territory, wherein the highest concentration of archaeological copper artefacts attributed to an early metallurgy period in the Cantabrian region is recorded (De Blas Cortina 2011). The whole group, formed by flat axes, ingots, unformed pieces and a little dagger fit this early metallurgical period in the Cantabrian region (De Blas Cortina 2007, 2011).. Figure 1 shows the location of the three prehistoric copper complexes of El Aramo, El Milagro and La Profunda in relation to the archaeological hoards where artefacts were found. 
Figure 1. Location of mines $(A)$ and hoards $(B)$ in Northwest lberia.

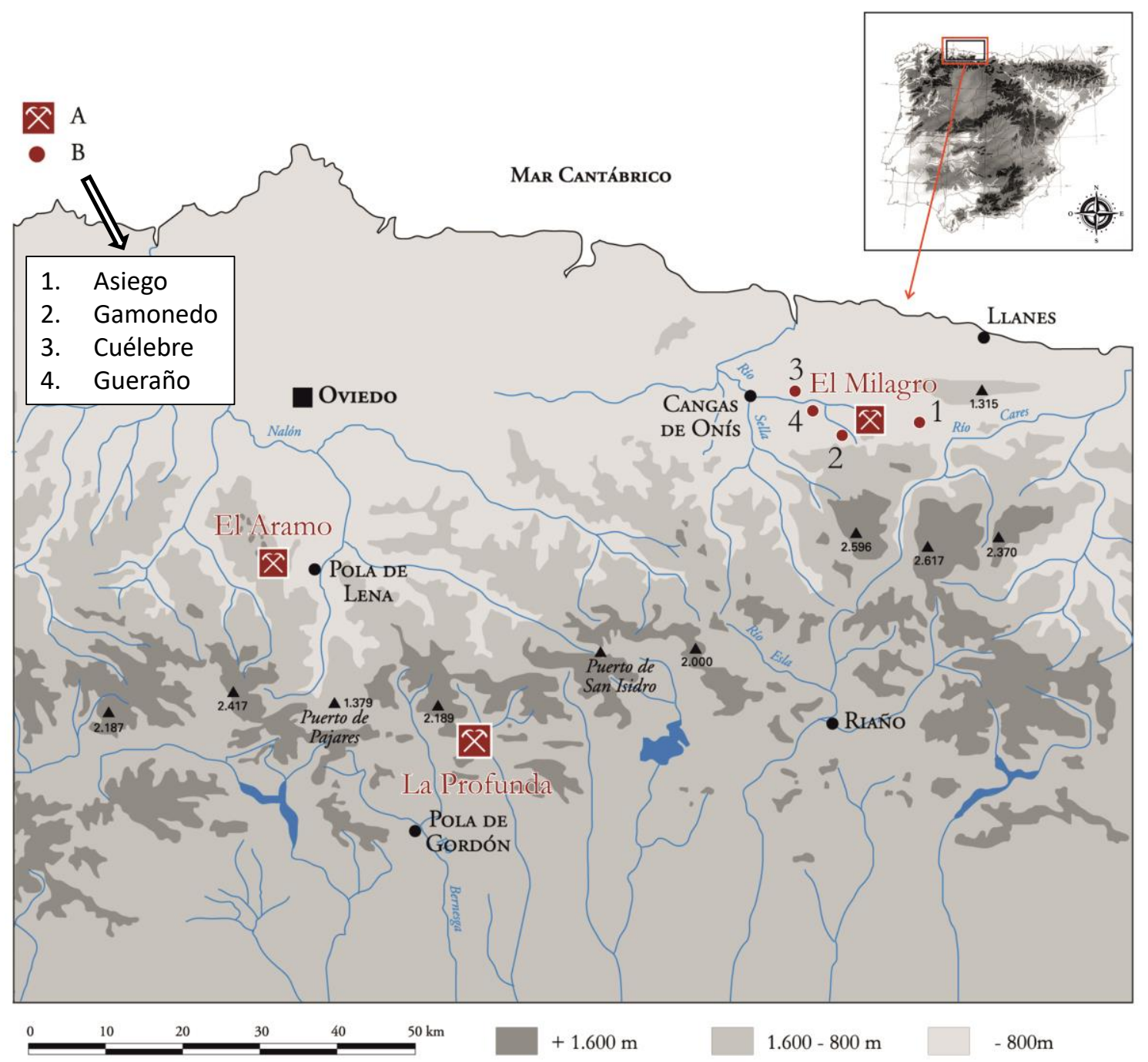

EXPERIMENTAL

\section{Samples investigated}

These 27 Bronze Age artefacts are part of the "The Neolithic and Metal Age" permanent exhibition at the Archaeological Museum of Asturias (Museo Arqueologico de Asturias, 2011). Photographs of the studied artefacts can be seen in the link 
provided in the reference. The artefacts were sampled many years ago and, as they are unique objects, less than $0.2 \mathrm{~g}$ per artefact in the form of metallic powder was obtained by drilling each surface without leaving any visible damage. No other samples for additional artefacts could be taken.

The Asiego hoard. This group of artefacts was found in Asiego, Cabrales council, in 1912, probably in a cave but without any detailed information. The whole hoard was deposited in the Archaeological Museum of Asturias around 1950. It is composed of a total number of 14 well-finished flat axes, of which only 11 were analysed. With a length ranging between $175-212 \mathrm{~mm}$ and an average weight of $850 \mathrm{~g}$ per object (around $11 \mathrm{~kg}$ of total weight), the high consumption of metal required for the melting process and the wide technical knowledge of the producers are undoubted (De Blas Cortina 1983, 2011). The typology is similar to other flat axes found in the north of Portugal and other areas in northwest Iberia and would correspond to the Early Bronze Age (ca. 2200-1700 BC) (De Blas Cortina, 1999).

The Gamonedo hoard. The set of 14 copper objects found in Gamonedo,Onís council, were discovered by chance in 1976 after a landslide. A flat axe $(127 \times 54 \times 13 \mathrm{~mm})$, ten ingots and three unformed metallic fragments, with a total weight of $3.5 \mathrm{~kg}$, had been carefully placed in a hole in the ground and carefully covered and protected with sherd fragments. This totally intentional storage was commonly employed in the Bronze Age to hide valuable objects (De Blas Cortina 1980). Ten out of these fourteen artefacts are plano-convex ingots coming presumably from a primary melting process. These semimanufactured products could represent an easy way to transport such amount of valuable material from the mining complexes to its final destination.

The Cueva del Cuélebre dagger. The dagger from Cueva del Cuélebre in Corao, Cangas de Onís council, was found in the second half of the XIX Century after the dismantling of the top strata of a wide shelter in the limestone cliff. In the same place a 
Neolithic polished axe was also found. The rectangular well-preserved little dagger ("puñalito"), with $175 \times 30 \times 2 \mathrm{~mm}$ dimensions and around $25 \mathrm{~g}$ of weight, shows morphological similarities to Bell-Beaker metallurgy artefacts (De Blas Cortina 1983). De Blas Cortina and Fernández-Tresguerres (1989) proposed that this artefact could have taken part of a funeral offering as this cave had been mainly employed for funeral services, although other previous or later purposes could not be discarded.

The Gueraño axe. The flat axe $(167 \times 51 \times 17 \mathrm{~mm}, 760 \mathrm{~g})$ found in Gueraño near Llano de Con, Onís council, under unknown circumstances shows a similar morphology to those of Asiego's axes (De Blas Cortina 1983). Drawings of the pieces from the hoards at Asiego and Gamonedo are illustrated in Figure 2. Photographs of all the pieces can be seen in the link provided in the reference to the Museo Arqueologico de Asturias. 
Figure 2. Drawings of the measured copper artefacts from the Asiego and Gamonedo hoards.

A) Asiego

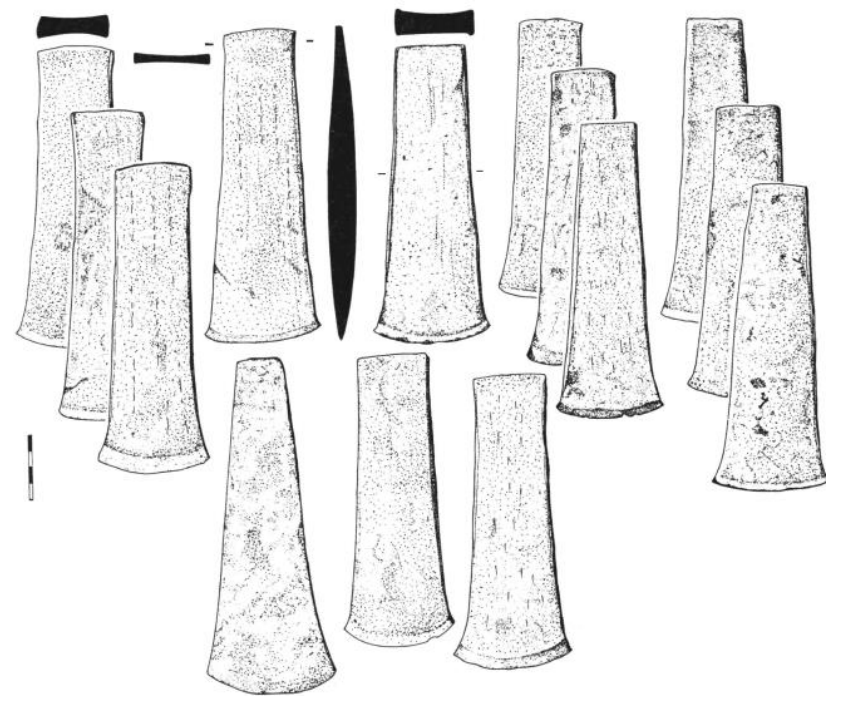

B) Gamonedo
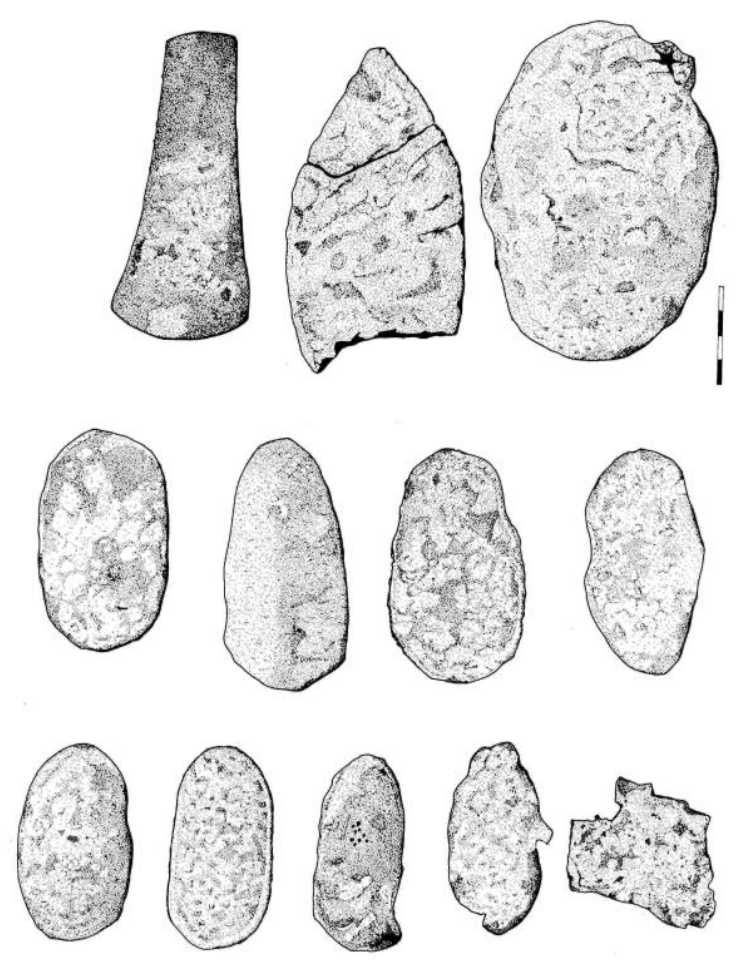


\section{Sample preparation}

Different amounts of sample ranging from 0.047 to $0.1041 \mathrm{~g}$, depending on sample availability, were placed in flat-bottom screw-cap Teflon (PFA) vials (Savillex ${ }^{\mathrm{TM}}$ ), and followed the acid digestion procedure described by Cattin et al. 2011. After subsequent evaporation to dryness, $2 \mathrm{~mL}$ of $1 \mathrm{M} \mathrm{HNO}_{3}$ were added, and the closed vials were heated at $110 \stackrel{\circ}{ } \mathrm{C}$ for $30 \mathrm{~min}$ for sample redissolution.

Finally, $200 \mu \mathrm{L}$ of this solution were transferred to a clean polypropylene tube and made up to a final volume of $10 \mathrm{~mL}\left(\mathrm{HNO}_{3} 2 \%, \mathrm{v} / \mathrm{v}\right)$ for the measurement of metallic impurities. Depending on the concentration level expected, further dilutions were made for metallic content determination by Q-ICP-MS (Agilent 7500ce, Tokyo, Japan). Weighted calibration curves for the quantification of Fe, Co, Ni, Zn, As, Ag, Sn, Sb, Au, $\mathrm{Pb}, \mathrm{Bi}$ and $\mathrm{U}$ were considered. $\mathrm{Y}$ and $\mathrm{Re}$ were used as internal standards to correct for matrix effects and instrument instability.

$\mathrm{Pb}, \mathrm{Cu}$ and $\mathrm{Sb}$ isotopic analysis was performed with the remaining $1.8 \mathrm{~mL}$ of sample. As isotope ratio measurement accuracy strongly depends on sample purity matrix removal was accomplished prior to isotopic analyses for lead and antimony. The protocol described by De Muynck and co-workers (2008) for lead isolation involving the use of a cationic exchange resin $\left(\mathrm{Pb} \mathrm{spec}{ }^{\mathrm{TM}}\right)$ was followed, as it had been described that no $\mathrm{Pb}$ fractionation was observed during the procedure. Detailed information about the whole separation protocol can be found elsewhere (Huelga-Suarez et al. 2012). In the case of copper, the fraction obtained during lead isolation was diluted and measured directly. This was possible because copper was the main component of the samples and no matrix effects could be expected at the high dilution factors employed. A fraction of this matrix was also considered for the evaluation of antimony isotopic natural variation, so a combination of a cationic exchange separation followed by an 
anionic exchange chromatographic step was conducted. Detailed information of this protocol can be found elsewhere (Lobo et al. 2012, 2013).

\section{Lead, copper and antimony isotope ratio measurement}

All isotope ratio measurements were conducted via a Thermo Scientific Neptune Plus multi-collector ICP-MS instrument (Bremen, Germany) operating in low-resolution mode $(m / \Delta m=400)$. Prior to lead isotope ratio measurement, the purified $\mathrm{Pb}$ fractions obtained after matrix removal were diluted with $0.14 \mathrm{M} \mathrm{HNO}_{3}$, adjusting the $\mathrm{Pb}$ concentration to $400 \mu \mathrm{g} \cdot \mathrm{L}^{-1}$ when possible. Blank correction was done and potential isobaric interference of ${ }^{204} \mathrm{Hg}^{+}$on ${ }^{204} \mathrm{~Pb}^{+}$was corrected for by controlling the intensity of ${ }^{202} \mathrm{Hg}^{+}$and assuming a value of 0.230 for the ${ }^{204} \mathrm{Hg} /{ }^{202} \mathrm{Hg}$ ratio (Berglund and Wieser 2011). All samples were run in a sample-standard-bracketing (SSB) sequence with a $400 \mu \mathrm{g} \cdot \mathrm{L}^{-1} \mathrm{~Pb}$ isotopic standard solution (NIST SRM 981), and NIST SRM $997 \mathrm{TI}$ isotopic standard was also added to samples and bracketing standards to obtain a concentration of $40 \mu \mathrm{g} \cdot \mathrm{L}^{-1}$, enabling instrumental mass bias correction by $\mathrm{Tl}-$ normalization (Baker et al. 2006; Rehkämper and Halliday 1998). The removal of outliers based on a 2s-test was done for isotope ratio calculation, and Russell equation was used as mass bias correction model (Huelga-Suarez et al. 2012).

Both samples for copper and antimony isotope ratio measurements were in a $0.42 \mathrm{M}$ $\mathrm{HNO}_{3}$ matrix run in a SSB sequence: a $1 \mathrm{mg} \cdot \mathrm{L}^{-1} \mathrm{Cu}$ and $\mathrm{Zn}$ in-house standards was employed for copper isotope ratio mass bias correction and another in-house standard solution of $1 \mathrm{mg} \cdot \mathrm{L}^{-1} \mathrm{Sb}$ and $1 \mathrm{mg} \cdot \mathrm{L}^{-1} \mathrm{In}$ was used for $\mathrm{Sb}$ analysis. For low Sb-containing samples a second in-house standard was used, $400 \mu \mathrm{g} \cdot \mathrm{L}^{-1} \mathrm{Sb}$ and $1 \mathrm{mg} \cdot \mathrm{L}^{-1} \mathrm{In}$, for a more accurate mass bias correction. Regarding sample availability, only 24 samples were analysed for $\mathrm{Sb}$ isotopic variation, and as arsenic could not be completely removed upon Sb purification, appropriate matrix-matching was conducted (Sb:As 
$\approx 100$ ). Removal of outliers based on a 2 s-test was done for both isotope ratio calculation and the revised Russell's law was applied (Baxter et al. 2006). $\delta^{65} \mathrm{Cu}$ values, employed to express the copper isotopic composition variations, were calculated with respect to the in-house standard (Lobo et al. 2014). Sb isotope ratio variations were expressed in $\varepsilon^{123} \mathrm{Sb}$ units, calculated in comparison to the in-house standard, whose theoretical value of ${ }^{123} \mathrm{Sb} /{ }^{121} \mathrm{Sb}$ was determined using the natural isotopic composition (Berglund and Wieser 2011). Both instrumental settings and acquisition parameters for metal trace analysis and isotope ratio determination are listed in the supplementary information (on-line only) Table S1.

\section{RESULTS AND DISCUSSION}

\section{Metal impurities}

The results obtained for metal impurities are given in Table 1. Although initially thought as bronze artefacts, the significant contribution of copper and the scarce presence of tin observed in the 27 samples after ICP-MS analysis (see Table 1), indicate that these objects were mainly produced of copper, and a copper-tin alloy composition could be discarded (please note that the tin content in Table 1 is given in $\mu \mathrm{g} / \mathrm{g}$ ). Arsenic is presented as a major constituent with concentrations ranging from 0.8 to $7.4 \%$, indicating a noteworthy arsenical nature of the copper ores used for the production of such artefacts, and allowing their classification into the arsenical copper E 01 group typical of the Iberian Peninsula, with an arsenic concentration range of $0.1-6 \%$ (Sangsmeister 1960). Hence, De Blas Cortina (1980) suggested that these artefacts could have been produced prior to the Bronze Age period as no high tin proportions were found, typical of later metallurgical techniques. The highest metal trace concentration, especially iron and uranium, is shown by the Gamonedo set of artefacts, 
mainly composed of ingots and unformed pieces. These objects are rich in impurities and they are supposed to derive from the first step in the manufacturing chain: the smelting of the ore. A second melting step should be sufficient to remove iron and other easily oxidized impurities as dross, and to refine the copper before casting and obtaining the final object (Pernicka 1999). This fact could explain the lower impurity contents found in the already finished axes and dagger from Asiego, Cueva del Cuélebre and Gueraño hoards In comparison with the Gamonedo samples. When comparing the samples from Asiego (axes) and Gamonedo (ingots) we observe a clear reduction of the contents of $\mathrm{Fe}, \mathrm{Co}, \mathrm{Zn}, \mathrm{Pb}$ and $\mathrm{U}$ while the contents of $\mathrm{Ni}, \mathrm{As}, \mathrm{Ag}, \mathrm{Sb}$ and $\mathrm{Bi}$ do not seem to be drastically affected. These results are in agreement with the calculations of Sabatini (Sabatini 2015) showing the strong affinity of arsenic to molten copper up to a $20 \%$ mole fraction of arsenic. The chemistry of $\mathrm{Sb}$ and $\mathrm{Bi}$ is similar to that of As while the chemistry of $\mathrm{Ni}$ and $\mathrm{Ag}$ is similar to that of $\mathrm{Cu}$. As an example, Figure S1 in the supplementary information shows the plot of the concentration of uranium vs. the concentration of lead in all samples measured. As it can be observed, the ingots from Gamonedo contained much higher levels of impurities than the finished samples from the other locations. So, impurity levels were mainly related to the ore processing level rather than to the origin of the ore used to cast the artefacts. We can assume that the ingots from the Gamonedo hoard derived from a first processing step and would not have been recycled as any recycling step would have decreased their impurity levels. 
Table 1. Concentration of impurities found in the artefacts. Metal concentration in $\mu \mathrm{g} / \mathrm{g}$ except for Fe and As which are given in \% w/w.

\begin{tabular}{|c|c|c|c|c|c|c|c|c|c|c|c|c|c|}
\hline Sample & Type & $\mathrm{Fe}(\%)$ & Co & $\mathbf{N i}$ & $\mathrm{Zn}$ & As (\%) & $\mathrm{Ag}$ & Sn & $\mathrm{Sb}$ & Au & $\mathbf{P b}$ & Bi & $\mathbf{U}$ \\
\hline AS-1 & axe & 0.006 & 14 & 33 & 30 & 3.08 & 91 & 0.28 & 318 & 0.23 & 331 & 304 & 0.004 \\
\hline AS-3 & axe & 0.001 & 3 & 158 & 3 & 2.77 & 26 & 0.09 & 264 & 0.23 & 28 & 242 & 0.003 \\
\hline AS-4 & axe & 0.003 & 3 & 222 & 10 & 4.24 & 40 & 0.15 & 123 & 0.15 & 91 & 47 & 0.023 \\
\hline AS-6 & axe & 0.004 & 1 & 297 & 1 & 1.72 & 40 & 0.18 & 175 & 0.22 & 19 & 105 & 0.0001 \\
\hline AS-8 & axe & 0.028 & 14 & 391 & 31 & 5.95 & 61 & 0.29 & 535 & 0.04 & 110 & 336 & 0.010 \\
\hline AS-9 & axe & 0.002 & 16 & 404 & 14 & 2.87 & 25 & 0.07 & 394 & 0.02 & 198 & 142 & 0.001 \\
\hline AS-10 & axe & 0.004 & 28 & 209 & 39 & 3.11 & 25 & 0.13 & 360 & 0.01 & 198 & 130 & 0.014 \\
\hline AS-11 & axe & 0.005 & 3 & 493 & 25 & 2.85 & 33 & 0.27 & 155 & 0.02 & 118 & 122 & 0.036 \\
\hline AS-12 & axe & 0.002 & 1 & 176 & 4 & 3.05 & 36 & 0.06 & 115 & 0.01 & 21 & 216 & 0.001 \\
\hline AS-13 & axe & 0.002 & 11 & 945 & 10 & 2.70 & 38 & 0.39 & 352 & 0.01 & 516 & 125 & 0.002 \\
\hline AS-14 & axe & 0.004 & 7 & 370 & 2 & 3.34 & 34 & 0.12 & 250 & 0.00 & 98 & 200 & 0.005 \\
\hline G-1 & axe & 3.79 & 15 & 66 & 24 & 1.33 & 122 & 3.66 & 230 & 0.02 & 154 & 150 & 2.26 \\
\hline G-2 & ingot & 3.55 & 763 & 630 & 2665 & 7.43 & 24 & 0.27 & 1147 & 0.19 & 2553 & 87 & 398 \\
\hline G-3 & ingot & 0.42 & 19 & 165 & 62 & 4.61 & 28 & 3.42 & 402 & 0.05 & 193 & 285 & 3.70 \\
\hline G-4 & ingot & 0.18 & 269 & 455 & 259 & 4.57 & 22 & 0.21 & 519 & 0.02 & 324 & 295 & 4.12 \\
\hline G-5 & ingot & 1.60 & 2 & 114 & 2 & 4.12 & 45 & 0.03 & 179 & 0.02 & 44 & 118 & 0.06 \\
\hline G-6 & ingot & 3.15 & 92 & 220 & 210 & 5.83 & 61 & 0.64 & 444 & 0.00 & 414 & 354 & 1.24 \\
\hline G-7 & ingot & 10.93 & 3174 & 2145 & 13837 & 6.25 & 19 & 1.50 & 711 & 0.02 & 5633 & 84 & 1491 \\
\hline G-8 & ingot & 0.02 & 38 & 237 & 126 & 3.87 & 32 & 0.07 & 240 & 0.05 & 657 & 59 & 0.08 \\
\hline G-9 & ingot & 0.04 & 9 & 197 & 15 & 4.25 & 18 & 0.06 & 301 & 0.02 & 191 & 140 & 0.79 \\
\hline G-10 & ingot & 0.12 & 369 & 487 & 307 & 5.12 & 17 & 0.37 & 486 & 0.03 & 683 & 103 & 0.41 \\
\hline G-11 & ingot & 0.07 & 45 & 280 & 88 & 5.41 & 29 & 0.22 & 263 & 0.00 & 951 & 55 & 0.01 \\
\hline G-12 & ingot & 0.41 & 256 & 228 & 590 & 0.83 & 44 & 0.30 & 648 & 0.01 & 817 & 177 & 38 \\
\hline G-13 & ingot & 0.35 & 317 & 285 & 831 & 7.22 & 18 & 0.57 & 626 & 0.00 & 872 & 166 & 1.55 \\
\hline G-14 & ingot & 0.13 & 163 & 193 & 460 & 6.24 & 30 & 0.40 & 487 & 0.00 & 711 & 136 & 6.32 \\
\hline Cuélebre & dagger & 0.002 & 32 & 938 & 0 & 1.71 & 84 & 1.47 & 835 & 0 & 89 & 86 & 0.02 \\
\hline Gueraño & axe & 0.02 & 4 & 323 & 142 & 2.78 & 17 & 5.10 & 176 & 0.1 & 338 & 97 & 0.06 \\
\hline
\end{tabular}


Table 2. $\mathrm{Pb}, \mathrm{Cu}$ and $\mathrm{Sb}$ isotope data in the measured artefacts.

\begin{tabular}{|c|c|c|c|c|c|c|c|c|c|c|c|c|c|c|c|}
\hline Sample & Type & ${ }^{206} \mathrm{~Pb} /{ }^{204} \mathrm{~Pb}$ & $2 s$ & ${ }^{207} \mathrm{~Pb} /{ }^{204} \mathrm{~Pb}$ & $2 s$ & ${ }^{208} \mathrm{~Pb} /{ }^{204} \mathrm{~Pb}$ & $2 s$ & ${ }^{207} \mathrm{~Pb} /{ }^{206} \mathrm{~Pb}$ & $2 s$ & ${ }^{208} \mathrm{~Pb} /{ }^{206} \mathrm{~Pb}$ & $2 s$ & $\delta^{65} \mathrm{Cu}$ & $\mathbf{s}$ & $\varepsilon^{123} \mathrm{Sb}$ & $\mathbf{s}$ \\
\hline AS-1 & axe & 30.1884 & 0.0169 & 16.2692 & 0.0113 & 38.5129 & 0.0327 & 0.53892 & 0.00010 & 1.27574 & 0.00041 & 0.13 & 0.05 & 1.43 & - \\
\hline AS-3 & axe & 34.2466 & 0.0114 & 16.4834 & 0.0060 & 38.5296 & 0.0156 & 0.48132 & 0.00004 & 1.12507 & 0.00016 & 0.14 & 0.00 & 4.14 & 0.55 \\
\hline AS-4 & axe & 20.1557 & 0.0079 & 15.7578 & 0.0069 & 38.5174 & 0.0186 & 0.78181 & 0.00007 & 1.91100 & 0.00026 & 0.09 & 0.05 & 1.21 & 0.17 \\
\hline AS-6 & axe & 33.9500 & 0.0138 & 16.4656 & 0.0076 & 38.5727 & 0.0192 & 0.48500 & 0.00005 & 1.13616 & 0.00021 & 0.11 & - & 0.92 & - \\
\hline AS-8 & axe & 36.5736 & 0.0124 & 16.6018 & 0.0058 & 38.5290 & 0.0149 & 0.45393 & 0.00004 & 1.05346 & 0.00012 & 0.13 & 0.00 & 2.41 & 0.18 \\
\hline AS-9 & axe & 27.9040 & 0.0094 & 16.1612 & 0.0064 & 38.5306 & 0.0178 & 0.57917 & 0.00005 & 1.38082 & 0.00021 & 0.24 & 0.01 & 1.82 & 0.24 \\
\hline AS-10 & axe & 25.4456 & 0.0101 & 16.0241 & 0.0074 & 38.4986 & 0.0196 & 0.62974 & 0.00007 & 1.51299 & 0.00026 & -0.07 & 0.09 & 0.76 & 0.56 \\
\hline AS-11 & axe & 21.7562 & 0.0086 & 15.8343 & 0.0073 & 38.5021 & 0.0202 & 0.72781 & 0.00009 & 1.76968 & 0.00032 & 0.14 & 0.02 & 0.96 & - \\
\hline AS-12 & axe & 36.4316 & 0.0185 & 16.5809 & 0.0085 & 38.5006 & 0.0224 & 0.45512 & 0.00005 & 1.05677 & 0.00019 & 0.46 & - & 0.25 & 0.18 \\
\hline AS-13 & axe & 22.1009 & 0.0107 & 15.8555 & 0.0090 & 38.5113 & 0.0286 & 0.71741 & 0.00008 & 1.74252 & 0.00041 & -0.15 & 0.03 & 3.80 & - \\
\hline AS-14 & axe & 27.6602 & 0.0080 & 16.1428 & 0.0053 & 38.5273 & 0.0132 & 0.58360 & 0.00005 & 1.39287 & 0.00018 & 0.13 & - & 2.37 & - \\
\hline G-1 & axe & 20.6884 & 0.0292 & 15.7497 & 0.0265 & 38.1054 & 0.0759 & 0.76130 & 0.00024 & 1.84195 & 0.00113 & 0.18 & 0.02 & - & - \\
\hline G-2 & ingot & 19.0138 & 0.0066 & 15.6936 & 0.0059 & 38.5046 & 0.0159 & 0.82538 & 0.00007 & 2.02508 & 0.00029 & 0.85 & - & 1.29 & 0.24 \\
\hline G-3 & ingot & 21.8887 & 0.0083 & 15.8373 & 0.0 & 38.5303 & 0.0163 & 0.72354 & 06 & 1.76027 & 022 & -0.08 & - & 5.19 & 0.35 \\
\hline G-4 & ingot & 27.9655 & 0.0090 & 16.1563 & 0.0059 & 38.5157 & 0.0141 & 0.57772 & 0.00005 & 1.37724 & 0.00018 & 0.00 & 0.03 & 1.38 & - \\
\hline G-5 & ingot & 23.5773 & 0.0108 & 15.9336 & 0.0084 & 38.5212 & 0.0222 & 0.67581 & 0.00007 & 1.63382 & 0.00026 & -0.05 & - & 2.60 & - \\
\hline G-6 & ingot & 21.7194 & 0.0074 & 15.8301 & 0.0065 & 38.4845 & 0.0198 & 0.72885 & 0.00011 & 1.77188 & 0.00042 & 0.14 & - & 1.71 & 0.21 \\
\hline G-7 & ingot & 19.4605 & 0.0061 & 15.7135 & 0.0056 & 38.4959 & 0.0140 & 0.80745 & 0.00009 & 1.97816 & 0.00026 & 0.64 & 0.02 & 4.82 & - \\
\hline G-8 & ingot & 19.7123 & 0.0064 & 15.7307 & 0.0053 & 38.5101 & 0.0147 & 0.79802 & 0.00006 & 1.95363 & 0.00019 & -0.19 & 0.02 & 1.90 & 0.21 \\
\hline G-9 & ingot & 24.4120 & 0.0082 & 15.9786 & 0.0060 & 38.5247 & 0.0166 & 0.65453 & 0.00007 & 1.57809 & 0.00026 & 0.02 & 0.01 & - & - \\
\hline G-10 & ingot & 22.6185 & 0.0072 & 15.8814 & 0.0061 & 38.5146 & 0.0173 & 0.70213 & 0.00007 & 1.70277 & 0.00028 & 0.05 & - & 1.48 & 0.03 \\
\hline G-11 & ingot & 19.4730 & 0.0070 & 15.7171 & 0.0062 & 38.5051 & 0.0177 & 0.80713 & 0.00008 & 1.97737 & 0.00034 & -0.27 & - & 1.61 & 0.39 \\
\hline G-12 & ingot & 21.9384 & 0.0059 & 15.9468 & 0.0053 & 38.5193 & 0.0143 & 0.72688 & 0.00010 & 1.75580 & 0.00035 & 0.03 & 0.00 & 1.11 & 0.07 \\
\hline G-13 & ingot & 21.9909 & 0.0067 & 15.8477 & 0.0050 & 38.5082 & 0.0130 & 0.72065 & 0.00006 & 1.75111 & 0.00019 & -0.07 & - & 0.67 & 0.21 \\
\hline G-14 & ingot & 21.9169 & 0.0094 & 15.8422 & 0.0068 & 38.5038 & 0.0183 & 0.72283 & 0.00007 & 1.75679 & 0.00022 & -0.16 & - & 0.88 & 0.11 \\
\hline Cuélebre & dagger & 26.1608 & 0.0148 & 16.0472 & 0.0093 & 38.4873 & 0.0250 & 0.61341 & 0.00007 & 1.47118 & 0.00029 & 0.30 & - & - & - \\
\hline Gueraño & axe & 21.0183 & 0.0093 & 15.7961 & 0.0074 & 38.5073 & 0.0189 & 0.75154 & 0.00007 & 1.83208 & 0.00021 & 0.04 & 0.05 & 1.80 & - \\
\hline
\end{tabular}




\section{Lead isotopic composition in ores from Spain}

The recently conducted study of malachite and azurite samples by Huelga-Suarez and co-workers $(2012,2014 a, 2014 b)$, allowed the characterization of the El Aramo, El Milagro and La Profunda mines (see Figure 1) in terms of lead isotopic composition, widening the lead isotope database on Spanish ores and facilitating provenance studies of archaeological artefacts. Previous studies (Arribas and Tosdal 1994; StosGale et al. 1995; Canals and Cardellach 1997; Hunt Ortiz 2003; Santos Zalduegui et al. 2004; Montero-Ruiz et al. 2006, 2009; Klein et al. 2009) showed the lead isotopic composition of other deposits in Spain. Based on those publications we have computed the most probable range of isotopic compositions from those deposits using robust statistics (Prichard and Barwick 2007). The median of the data points published was computed together with the robust standard deviation calculated as $1.483 \times$ MAD where MAD is the median of the absolute deviations from the median of the data points. Those most probable ranges are given in Table S2 in the on-line supplementary information. As it can be observed, the most discriminating ratios between the different sources are the $207 / 206,208 / 206$ and $206 / 204$. The ratios $207 / 204$ and $208 / 204$ are fairly constant between the different locations. The clearly radiogenic characteristics of lead isotopes in the three local mines (Aramo, Milagro, Profunda), with a 206/204 ratio higher than 19, makes them easily differentiated from other sources within Spain.

\section{Lead isotopic composition of the measured artefacts}

The measured lead isotope ratios of the objects studied in the present work are summarised in Table 2, and a visual representation together with the most probable ranges for Spanish ores is shown in Figure 3 (207/206 vs 208/206) Figure 3A compares the artefacts with the ranges observed for the three local mines while Figure 3B compares the artefacts with other published data for Spain, particularly the 
Northeast, Southeast and Southwest. The same representation for the ratios 207/204 vs $206 / 204$ in comparison with the three local mines is given in the supplementary information Figure S2. As it can be seen in Figure 3A, these three northern mines exhibit a highly radiogenic lead isotopic fingerprint characterised by low ${ }^{208} \mathrm{~Pb} /{ }^{206} \mathrm{~Pb}$ and ${ }^{207} \mathrm{~Pb} /{ }^{206} \mathrm{~Pb}$ values, high $207 / 204$ and $206 / 204$ values and a larger isotopic variability, clearly different from that of the rest of the Spanish ores (Figure 3B) and also from other European and Mediterranean metal-producing regions (Huelga-Suárez and coworkers, 2014b). It is clear that the uniqueness of the El Aramo, El Milagro and La Profunda mines is undoubted. As it can be also observed in Figure 3A, the lead isotope ratios found in the whole group of artefacts studied show a remarkable radiogenic nature $\left({ }^{206} \mathrm{~Pb} /{ }^{204} \mathrm{~Pb}: 19.014-36.574,{ }^{207} \mathrm{~Pb} /{ }^{206} \mathrm{~Pb}: 0.454-0.825,{ }^{208} \mathrm{~Pb} /{ }^{206} \mathrm{~Pb}: 1.053-\right.$ 2.025) and fall within the variation interval of these three mines. In the case of Figure 3B only a few samples from Los Pedroches (Córdoba) overlap with two of the samples from Gamonedo. However, by looking at the probable ranges shown in Table S2, computed from 49 data points from Los Pedroches, none of the samples overlap with other Spanish ores. So, we are proposing this three local mines as potential ore source candidates. We have to take into account also their extensive production during the Bronze Age period and proximity to the hoards.

Careful attention was paid to the historical information of each hoard in combination to lead isotope ratio results obtained. At this stage, we dare to say that at least 10 of the 11 axes from the Asiego hoard were made with copper from La Profunda mine, and that El Milagro mine could be the source of the other one (AS-4). Dated back to $2200-$ 1700 cal. BC (Early Bronze age), in a "development stage of the metallurgical regional societies", the morphology of these objects seems to resemble to that of the dominant types of north-western Iberia, in particular to those in the Duero-Miño interfluvial region (De Blas Cortina 1999). The high proportion of La Profunda-derived copper artefacts suggests that the whole set could have been produced from ores obtained in this mine 
(see below for copper isotope ratios) On the other hand, the dagger from Cueva del Cuélebre was manufactured clearly from ores from La Profunda mine while the axe from Gueraño could have originated either from La Profunda or El Milagro mines. Finally, the ingots from Gamonedo show variable compositions. It seems that 9 out of the 14 samples originated from La Profunda while the 5 other samples could originate both from El Milagro or El Aramo mines.

Figure $3 A$. Pb dual isotope ratio plot $207 / 206$ vs. $208 / 206$ for the measured samples. The most probable isotope ratio ranges for the three known local mines are also shown.

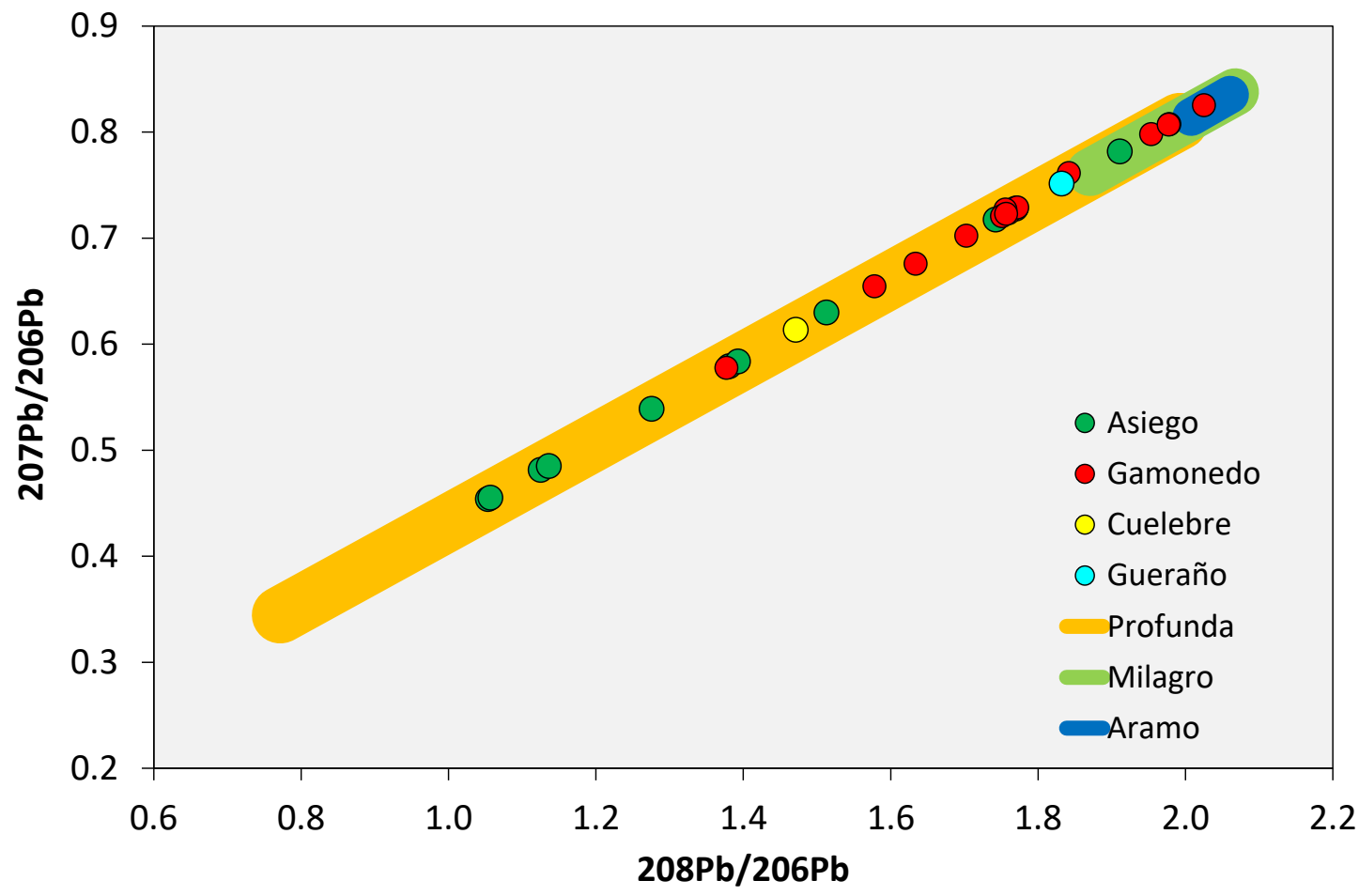


Figure 3B. Pb dual isotope ratio plot $207 / 206$ vs. $208 / 206$ for the measured samples in comparison with other published ores from the Iberian Peninsula (triangles, top right of the graph, for details see text).

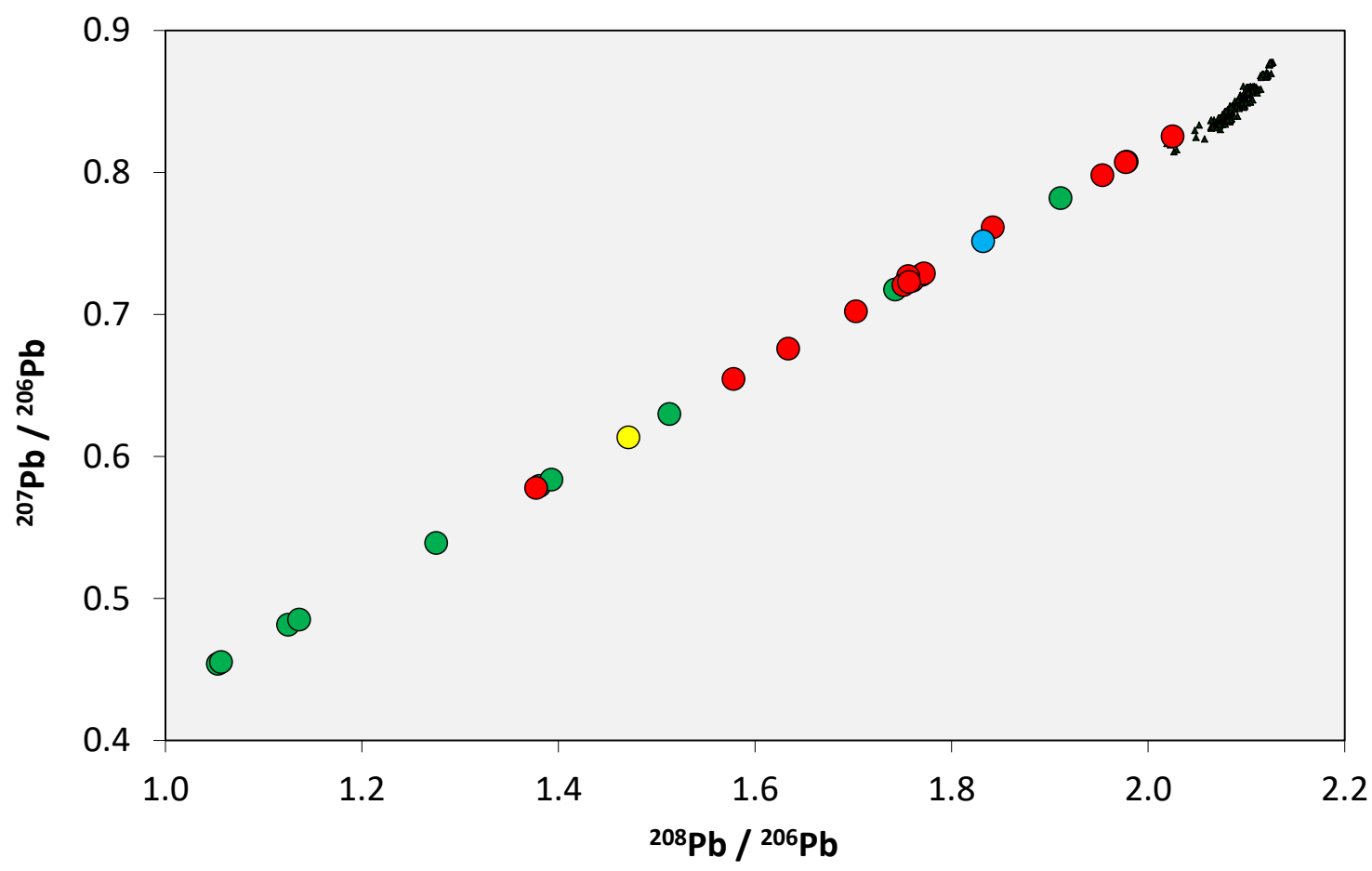

\section{Copper and antimony isotope compositions}

The obtained data for copper and antimony isotope compositions are given in Table 2. Unfortunately, no similar data on the ores from the three local mines exist so its comparison with the source cannot be done. However, we could compare the artefacts themselves and see if they help to differentiate them when the lead isotope ratios fail. So, Figure 4 shows the obtained copper $\delta 65$ data vs the 207/206 lead data. We have also included the copper $\delta 65$ data vs the 206/204 lead data in Figure S3 of the supplementary information. As can be observed in both Figures the copper isotopic composition from samples G-2 and G-7 is clearly different from the rest of samples. Additionally, they have the highest 207/206 ratio and lowest 206/204 ratio which clearly falls within the El Aramo range also shown. We think that those two samples could have been originated from El Aramo ores but as no copper data from the mines exist 
this assignment has to be done with caution. On the other hand, samples G-8 and G11 have also a high 207/206 ratio but the lowest $\delta 65$ values within the samples investigated. Those two samples have a lead isotopic signature within the range shown by El Milagro mine but they appear also on the edge of the range for La Profunda Mine. In our opinion, the rest of the samples originated from ores mined in La Profunda but three of those samples also fall within the lead isotope ranges of El Milagro mine. So, for these three samples the assignment to La Profunda or El Milagro could be dubious.

Unfortunately, the antimony isotope composition shown in Table 2 seems to be randomly distributed and it could not be employed for sourcing purposes. The reason for this random distribution could be due to measurement variability as the range observed for the natural variability of antimony is very small (in the $\varepsilon$ range).

Figure 4. $\delta^{65} \mathrm{Cu}$ isotope ratio data for the measured samples vs. $207 / 206 \mathrm{~Pb}$.

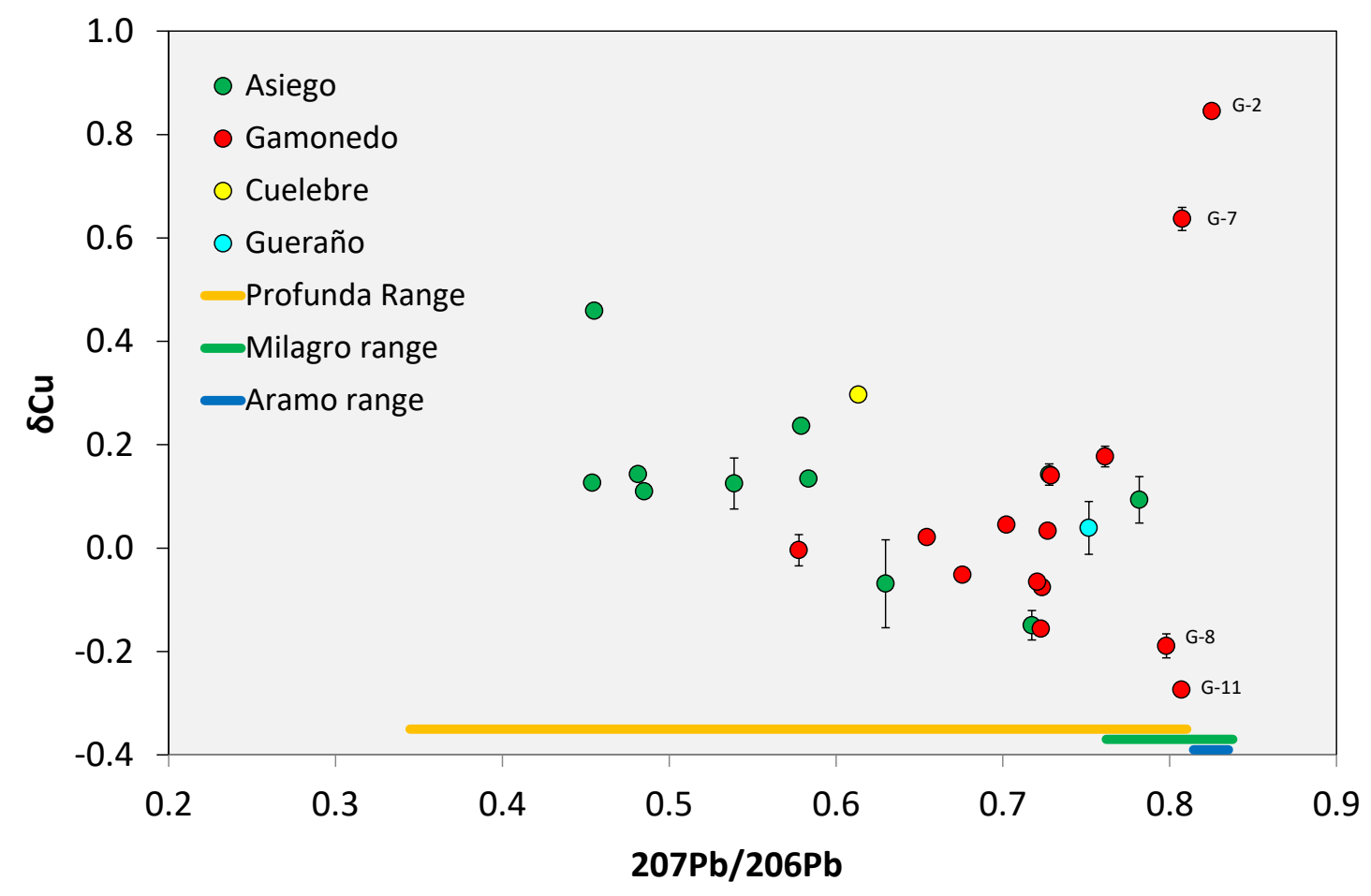


Nowadays, archaeology and analytical chemistry form an essential tandem for investigating the past. Advances in analytical methods, such as the measurement of copper isotope compositions, will have a profound influence in the information that can be obtained from archaeological artefacts. In this paper, the combination of lead and copper isotope compositions was employed to distinguish ores with similar lead isotope compositions with partial success. It is clear that these three local mines are the source of the ore employed in the manufacture of all these copper artefacts as their lead isotopic composition do not fit with any other location within Spain. Mine La Profunda seems to be the origin of most artefacts (23 out of 27) while mines El Aramo and El Milagro could have been the sources of two artefacts each. It is important to stress that the hoard from Asiego (14 axes of similar manufacture style, 11 of them analysed here) seems to be manufactured entirely from ores mine in La Profunda while the hoard from Gamonedo (13 ingots and one axe) is of mixed precedence (10 artefacts from La Profunda and possibly two artefacts each from El Aramo and El Milagro). Finally, these results confirm previous suggestions (Soler 1883) indicating that La Profunda mine was one of the main sources of copper ore in the Early Bronze Age in spite of the fact that the archaeological remains in this mine are much more ambiguous in comparison with both El Aramo and El Milagro. Detailed data on La Profunda mine, including the archaeological context, can be found in a previous publication (Huelga Suarez et al 2014b).

It is clear that isotopic measurements demonstrate that the processes for distribution and exchange of copper in the past were always complex (Needham 2002) and that the closeness of a particular mine does not indicate that the copper artefacts found in the vicinity must have come from this mine. The case of El Milagro mine is a clear example. The hoards found in Asiego and Gamonedo are close to this mine but the isotopic information indicates that the main origin of the material is La Profunda mine, 
ca. $100 \mathrm{Km}$ away. The ancient works at La Profunda seem to have been of enormous proportions. The big cave is $50 \mathrm{~m}$ in diameter and at least $200 \mathrm{~m}$ deep. They have calculated (Soler 1883) that at least 18000 cubic meters of rocks and minerals could have been extracted. So, a lot of copper could have been obtained from this mine. On the other hand, the ancient works at El Aramo and El Milagro seem to have been of a much smaller scale. So, the large availability of copper from La Profunda in ancient time may be the reason for our findings.

\section{ACKNOWLEDGEMENTS}

This work was supported by grant CTQ2015-70366-P from the Spanish Ministry of Economy and Competitiveness (co-funded by FEDER). A.R.G thanks the provision of a doctorate grant to FICYT. We thank Museo Arqueológico de Asturias for the supply of the samples.

\section{REFERENCES}

Albarède, F., Desaulty, A-M., Blichert-Toft, J., 2012, A geological perspective on the use of $\mathrm{Pb}$ isotopes in archaeometry, Archaeometry, 54, 853-867.

Arribas, A., and Tosdal, R.M., 1994, Isotopic composition of $\mathrm{Pb}$ in ore deposits of the Betic Cordillera, Spain; origin and relationship to other European deposits, Economic Geology, 89, 1074-93. 
Armarda, X-L., Garcia I Rubert, D., Montero, I., Moreno, I., Rafel, N., Rovira, M.C., 2005, Minería y metalurgia durante la I Edad del Hierro. Procesos de cambio en el sur de Catalunya, Revista d'Arqueología de Ponent, 15, 133-150.

Baker, J., Stos, S., and Waight, T., 2006, Lead isotope analysis of archaeological metals by multiple-collector inductively coupled plasma mass spectrometry, Archaeometry, 48, 45-56.

Balcaen, L., Moens, L., Vanhaecke, F., 2010, Determination of isotope ratios of metals (and metalloids) by means of inductively coupled plasma-mass spectrometry for provenancing purpose - A review, Spectrochimica Acta Part B, 65, 769-786.

Balliana, E., Aramendía, M., Resano, M., Barbante, C., Vanhaecke, F., 2013, Copper and tin isotopic analysis of ancient bronzes for archaeological investigation: development and validation of a suitable analytical methodology, Analytical and Bioanalytical Chemistry, 405, 2973-2986.

Baron, S., Tămaş, C.G., and Le Carlier, C., 2014, How mineralogy and geochemistry can improve the significance of $\mathrm{Pb}$ isotopes in metal provenance studies, Archaeometry, 56, 665-680.

Baxter, D.C., Rodushkin, I., Engström, E., and Malinovsky, D., 2006, Revised exponential model for mass bias correction using an internal standard for isotope abundance ratio measurements by multi-collector inductively coupled plasma mass spectrometry, Journal of Analytical Atomic Spectrometry, 21, 427-430.

Berglund, M., and Wieser, M.E., 2011, Isotopic compositions of the elements 2009 (IUPAC Technical Report), Pure and Applied Chemistry, 83, 397-410.

Brill, R.H., and Wampler, J.M., 1965, Isotope studies of ancient lead, American Journal of Archaeology, 69, 165-166. 
Budd, P., Haggery, R., Ixer, R.A., Scaife, B. and Thomas, R.G. (2000) Copper deposits in south-west England identified as a source of Copper Age metalwork. Website: https://www.aditnow.co.uk/documents/personal-album-272/Copper-deposits-in-southwest-England.pdf. Accessed June 2018

Canals, A., and Cardellach, E., 1997, Ore lead and sulphur isotope pattern from the low-temperature veins of the Catalonian Coastal Ranges (NE Spain), Mineralium Deposita, 32, 243-49

Carbonell Trillo-Figueroa, A., 1954, Noticias sobre antecedentes romanos y otros de las minas de Cerro Muriano, Boletín de la Real Academia de Córdoba, 70, 106-108.

Catanzaro, E.J., Murphy, T.J., Shields, W.R., and Garner, E.L., 1968, Absolute isotopic abundance ratios of common, equal-atom and radiogenic lead isotopic standards, Journal of Research of the National Bureau of Standards - A. Physics and Chemistry, 72A, 3, 261-267.

Cattin, F., Guénette-Beck, B., Curdy, P., Meisser, N., Ansermet, S., Hofmann, B., Kündig, R., Hubert, V., Wörle, M., Hametner, K., Günther, D., Wichser, A., Ulrich, A. Villa, I.M., and Besse, M., 2011, Provenance of Early Bronze Age metal artefacts in Western Switzerland using elemental and lead isotopic compositions and their possible relation with copper minerals of the nearby Valais, Journal of Archaeological Science, 38, $1221-1233$.

De Blas Cortina, M. Á., 1980, El depósito de materiales de la Edad del Bronce de Gamonedo (Asturias), Zephyrus, XXX-XXXI, vol. 30, 268-276. Universidad de Salamanca.

De Blas Cortina, M. Á., 1983, La Prehistoria Reciente en Asturias. Estudios de Arqueología Asturiana nำ. Fundación Pública de Cuevas y Yacimientos Prehistóricos de Asturias. Consejería de Cultura del Principado de Asturias. 
De Blas Cortina, M. Á., 1996, La primera minería metálica del N. peninsular: las indicaciones del C-14 y la cronología prehistórica de las explotaciones cupríferas del Aramo y El Milagro, Complutum Extra, 6, 217-226.

De Blas Cortina, M. Á., 1999, Asturias y Cantabria”. Las primeras etapas metalúrgicas en la península Ibérica. II. Estudios regionales. G. Delibes de Castro e I. Montero Ruiz, coords. Madrid. Instituto Universitario Ortega y Gasset. Fundación Ortega y Gasset y Ministerio de Educación y Cultura, 41-62.

De Blas Cortina, M. Á., 2005, Un témoignage probant de l'exploitation préhistorique du cuivre dans le nord de la péninsule ibérique: le complxe minier de l'Aramo, Memoires de la Socièté Préhistorique Française, 37, 195-205.

De Blas Cortina, M. Á., 2007, Minería prehistórica del cobre en el reborde septentrional de los Picos de Europa: las olvidadas labores de "El Milagro" (Onís, Asturias), Veleia, 24-5. Universidad del País Vasco, 723-753.

De Blas Cortina, M. Á., 2010, El expolio del subsuelo y las prácticas rituales de la minería prehistórica: a propósito del hallazgo de esqueletos humanos en las explotaciones de cobre en Asturias, in Cobre y oro. Minería y metalurgia en la Asturias prehistórica y antigua, 127169, Principado de Asturias, Real Instituto de Estudios Asturianos, Oviedo. [ISBN 978-84-87212-94-9].

De Blas Cortina, M.Á., 2011, De la caverna al lugar fortificado: una mirada a la Edad del Bronce en el territorio Astur-Cántabro, Quaderns de Prehistòria i Arqueologia de Castelló, 29, 105-134. [ISSN: 1137.0793].

De Blas Cortina, M. Á., 2014, El laboreo del cobre en la Sierra del Aramo (Asturias) como referente cardinal de la minería prehistórica en la región cantábrica. Los paisajes mineros de la península ibérica: la minería metálica en la antigüedad. Cuadernos de Prehistoria y Arqueología de la Universidad de Granada 24, 45-84. 
De Blas Cortina, M.Á., and Fernández-Treguerres, J., 1989, Historia primitiva de Asturias, Gijón. [ISBN 84-7286-279-8].

De Blas Cortina, M.Á., and Suárez Fernández, M., 2009, Utillaje faunístico inédito de las labores de cobre prehistóricas de La Profunda (León) y su datación C14 (AMS), Zephyrus, 64, 5-18. [ISSN: 0514-7336].

De Blas Cortina, M.Á., and Suárez Fernández, M., 2010, Minería subterránea del cobre en Asturias: un capítulo esencial en la Prehistoria reciente del norte de España, in Cobre y oro. Minería y metalurgia en la Asturias prehistórica y antigua, 43-82, Principado de Asturias, Real Instituto de Estudios Asturianos, Oviedo. [ISBN 978-8487212-94-9].

De Muynck, D.; Cloquet, C., and Vanhaecke, F., 2008, Development of a new method for $\mathrm{Pb}$ isotopic analysis of archaeological artefacts using single-collector ICP-dynamic reaction cell-MS, Journal of Analytical Atomic Spectrometry, 23, 62-71.

Desaulty, A-M., Telouk, P., Albalat, E., Albarède, F., 2011, Isotopic Ag-Cu-Pb record of silver circulation through $16^{\text {th }}-18^{\text {th }}$ century Spain, Proceedings of the National Academy of Sciences of the United States of America, 108, 9002-9007.

Durali-Mueller, S., Peter Brey, G., Wigg-Wolf, D., and Lahaye, Y., 2007, Roman lead mining in Germany: its origin and development through time deduced from lead isotope provenance studies, Journal of Archaeological Science, 34, 1555-1567.

Fuste, M., 1982, Restos humanos de la Cueva de los Hombres Verdes en Urbiola (Navarra), Trabajos de Arqueología Navarra, 2, 3-41.

Gale, N.H., Woodhead, A.P., Stos-Gale, Z.A., Walder, A., Bowen, I., 1999, Natural variations detected in the isotopic composition of copper: possible applications to archaeology and geochemistry, International Journal of Mass Spectrometry, 184, 1-9. 
Gómez Ramos, P., 1993, Tipología de lingotes de metal y su hallazgo en los depósitos del Bronce Final de la Península Ibérica, Cuadernos de Prehistoria y Arqueología de la Universidad Autónoma de Madrid, 20, 73-105.

Grögler, N., Geiss, J., Grünenfelder,M., and Houtermans, F.G., 1966, Isotopenuntersuchungen zur Bestimmung der Herkunft römischer Bleirohre und Bleibarren, Zeitschrift für Naturforschung, 21a, 1167-1172.

Haustein, M., Gillis, C., Pernicka, E., 2010, Tin isotopy - A new method for solving old questions, Archaeometry, 52, 816-832.

Huelga-Suarez, G., Moldovan, M., Suárez Fernández, M., De Blas Cortina, M.A., Vanhaecke, F., and García Alonso, J.I., 2012, Lead isotopic analysis of copper ores from the Sierra El Aramo (Asturias, Spain), Archaeometry, 54, 685-697.

Huelga-Suarez, G., Moldovan, M., Suárez Fernández, M., De Blas Cortina, M. Á., and García Alonso, J.I., 2014a, Defining the lead isotopic fingerprint of copper ores from north-west Spain: The El Milagro Mine (Asturias), Archaeometry, 56, 88-101.

Huelga-Suarez, G., Moldovan, M, Suárez Fernández, M., De Blas Cortina, M. Á., and García Alonso, J.I., 2014b, Isotopic composition of lead in copper ores and a copper artefact from the La Profunda mine (León, Spain), Archaeometry, 56, 651-664.

Hunt Ortiz, M. A., 2003, Prehistoric Mining and Metallurgy in south-west Iberian Peninsula, BAR International Series 1188, Archaeopress, Oxford

Klassen, L., Stürup, S., 2001. Decoding the Riesebusch-copper: Lead-isotope analysis applied to early neolithic copper finds from south Scandinavia. Praehistorische Zeitschrift 76/1, 55-72.

Klein, S., Lahaye, Y., Brey, G.P., Von Kaenel, H-M., 2004, The early roman imperial aes coinage II: tracing the copper sources by analysis of lead and copper isotopes copper coins of Augustus and Tiberius, Archaeometry, 46, 469-480. 
Klein, S., Domergue, C., Lahaye, Y., Brey, G. P., and von Kaenel, H. M., 2009, The lead and copper isotopic composition of copper ores from the Sierra Morena (Spain), Journal of Iberian Geology, 35, 59-68

Klein, S., Brey, G.P., Durali-Müller, S., Lahaye, Y., 2010, Characterisation of the raw metal sources used for the production of copper and copper-based objects with copper isotopes, Archaeological and Anthropological Sciences, 2, 45-56.

Kuleff, I., Iliev, I., Pernicka, E., Gergova, D., 2006, Chemical and lead isotope compositions of lead artefacts from ancient Thracia (Bulgaria), Journal of Cultural Heritage, 7, 244-256.

Ling, J., Hjärthner-Holdar, E., Grandin, L., Billström, K., Persson, P-O., 2013, Moving metals or indigenous mining? Provenancing Scandinavian Bronze Age artefacts by lead isotopes and trace elements, Journal of Archaeological Science, 40, 291-304.

Ling, J., Stos-Gale, Z., Grandin, L., Billström, K., Hjärthner-Holdar, E., Persson, P-O., 2014, Moving metals II: provenancing Scandinavian Bronze Age artefacts by lead isotope and elemental analyses, Journal or Archaeological Science, 41, 106-132.

Lobo, L., Devulder, V., Degryse, P., and Vanhaecke, F., 2012, Investigation of natural isotopic variation of $\mathrm{Sb}$ in stibnite ores via multi-collector ICP-mass spectrometry perspectives for $\mathrm{Sb}$ isotopic analysis of Roman glass, Journal of Analytical Atomic Spectrometry, 27, 1304-1310.

Lobo, L., Degryse, P., Shortland, A., and Vanhaecke, F., 2013, Isotopic analysis of antimony using multi-collector ICP-mass spectrometry for provenance determination of Roman glass, Journal of Analytical Atomic Spectrometry, 28, 1213-1219.

Lobo, L., Degryse, P., Shortland, A., Eremin, K., and Vanhaecke, F., 2014, Copper and antimony isotopic analysis via multi-collector ICP-mass spectrometry for provenancing ancient glass, Journal of Analytical Atomic Spectrometry, 29, 58-64. 
Montero-Ruiz, I., Gener, M., Renzi, M., Hunt, M., Rovira, S., and Santos-Zalduegui, J. F., 2006. Provenance of lead in first Iron Age sites in Southern Catalonia (Spain), in Proceedings ISA 2006, (eds. J. F. Moreau, R. Auger, J. Chabot and A. Herzog), 391-8, Quebec.

Montero-Ruiz, I., Rafel, N., Hunt, M., Murillo-Barroso, M., Rovira, C., Armada, X. L., and Graells, R., 2009, Pre-roman mining activities in the El Molar-Bellmunt-Falset district (Tarragonia, Spain): indirect proofs based on lead isotopes analysis, in Mining in European History and its Impact on Environment and Human Societies. Proceedings for the 1st Mining in European History-Conference of the SFB-HIMAT, Innsbruck, 12.15. November 2009 (eds. P. Anreiter, G. Goldenberg, K. Hanke, R. Krause, W. Leitner, F. Mathis, K. Nicolussi, K. Oeggl, E. Pernicka, M. Prast, J. Schibler, I. Schneider, H. Stadler, T. Stöllner, G. Tomedi and P. Tropper), 115-21, Innsbruck University Press, Innsbruck

Mu, D., Song, G., Cui, B., Wang, H., Wang, W., and Luo, W., 2014, Provenance study on Chinese bronze artefacts of E in the Zhou Dynasty by lead isotope analysis, Journal of Archaeological Science, 52, 515-523.

Museo Arqueologico de Asturias 2011. Last accessed June 2018.

https://www.museoarqueologicodeasturias.com/sites/default/files/2 Neolitico-EdadMetales 0.pdf

Needham, S., 2002. "Analytical implications for Beaker metallurgy in north-west Europe", M. Bartelheim, ER. Pernicka \& R. Krause (eds.), Die Anfängue der Metallurgie in der Alten Welt. Freiberger Forschungen zur Archcäeometrie und Kulturgesch. 1, 99-133.

Niederschlag, E., Pernicka, E., Seifert, Th., Bartelheim, M., 2003, The determination of lead isotope ratios by multiple collector ICP-MS: A case study of Early Bronze Age 
artefacts and their possible relation with ore deposits of the Erzgebirge, Archaeometry, 45, 61-100.

Paniagua, A., Rodríguez-Pevida, L.S., Garzón, L, Pérez, J.M., and Quintana, A., 1987, Presencia de una paragénesis Cu-Ni-Co-U-As-S en la zona cantábrica: la Mina Profunda (Cármenes, León), Geogaceta, 2, 22-24.

Pernicka, E, 1999, Trace element fingerprinting of ancient copper: A guide to technology or provenance? In: Young, S.M.M., Pollard A.M., Budd, P., Ixer, R.A. (Eds), Metals in Antiquity BAR International Series, vol. 792. Archaeopress, Oxford, pp. 163171.

Pollard, M., Batt, C., Stern, B., Young, S.M.M., 2007, Analytical Chemistry in Archaeology, Cambridge University Press, Cambridge

Prichard, E., Barwick, V., 2007, "Quality Assurance in Analytical Chemistry" John Wiley and Sons, Chichester, UK. Rehkämper, M., and Halliday, A.N., 1998, Accuracy and long-term reproducibility of lead isotopic measurements by multiple-collector inductively coupled plasma mass spectrometry using an external method for correction of mass discrimination, International Journal of Mass Spectrometry, 181, 123-133.

Rehren, Th., Pernicka, E., 2008, Coins, artefacts and isotopes - Archaeometallurgy and archaeometry, Archaeometry, 50, 232-248.

Resongles, E., Freydier, R., Casiot, C., Viers, J., Chmeleff, J., 2015, Antimony isotopic composition in river waters affected by ancient mining activity, Talanta, 144, 851-861.

Rouxel, O., Ludden, J., Fouquet, Y., 2003, Antimony isotope variations in natural systems and implications for their use as geochemical tracers, Chemical Geology, 200, $25-40$. 
Rovira, S., Renzi, M., 2013. Plata tartésica: una revisión de la tecnología extractiva a la luz de nuevos hallazgos. In: Campos, J.M., Alvar, J. (Eds.), Tarteso. El Emporio del Metal. Almuzara, Huelva, pp. 473-488.

Sabitini, B (2015) The As-Cu-Ni System: A Chemical Thermodynamic Model for Ancient Recycling. JOM: the journal of the Minerals, Metals \& Materials Society 67

Sangmeister, E., 1960, Metalurgia y comercio del cobre en la Europa prehistórica, Zephyrus, 11, 131-140, [ISSN 0514-7336].

Santos Zalduegui, J. F., García de Madinabeitia, S., Gil Ibarguchi, J. I., and Palero, F., 2004, A lead isotope database: the Los Pedroches-Alcudia area (Spain); implications for archaeometallurgical connections across southwestern and southeastern Iberia, Archaeometry, 46, 625-34

Soler, J.N., 1883, Reseña geológico-minera de la provincial de León y catálogo de minerales, rocas, fósiles, antigüedades, productos metalúrgicos, cerámica y aguas remitidos por la Jefatura de Minas a la Exposición de Minería de Madrid, León.

Stos-Gale, Z., Gale, N.H., Houghton, J., and Speakman, R., 1995, Lead isotope data from the Isotrace Laboratory, Oxford: archaeometry data base 1, ores from western Mediterranean, Archaeometry, 37, 407-15

Thibodeau, A.M., Chesley, J.T., and Ruiz, J., 2012, Lead isotope analysis as a new method for identifying material culture belonging to the Vázquez de Coronado expedition, Journal of Archaeological Science, 39, 58-66.

Villa, I.M., 2009, Lead isotopic measurements in archaeological objects, Archaeological and Anthropological Sciences, 1, 149-153. 
Webb, J.M., Frankel, D., Stos, Z.A., and Gale, N., 2006, Early Bronze Age metal trade in the eastern Mediterranean. New compositional and lead isotope evidence from Cyprus, Oxford Journal of Archaeology, 25, 261-288.

Yener, K.A., Sayre, E.V., Joel, E.C., Özbal, H., Barnes, I.L., and Brill, R.H., 1991, Stable lead isotope studies of Central Taurus ore sources and related artefacts from eastern Mediterranean chalcolithic and Bronze Age sites, Journal of Archaeological Science, 18, 541-577. 